\title{
Capturing Cross-Section of Return on Nifty 100 Companies: CAPM vs Fama-French Three-Factor Model
}

\author{
Deepak Sehgal ${ }^{1, *}$, Khushboo Sagar $^{2}$ \\ ${ }^{1}$ Deen Dayal Upadhyaya College, Delhi University, India \\ ${ }^{2}$ Indraprastha College for Women, Delhi University, India
}

Received October 27, 2021; Revised January 1, 2022; Accepted January 26, 2022

\section{Cite This Paper in the following Citation Styles}

(a): [1] Deepak Sehgal, Khushboo Sagar, "Capturing Cross-Section of Return on Nifty 100 Companies: CAPM vs Fama-French Three-Factor Model," Universal Journal of Accounting and Finance, Vol. 10, No. 2, pp. 444 - 449, 2022. DOI: 10.13189/ujaf.2022.100208.

(b): Deepak Sehgal, Khushboo Sagar (2022). Capturing Cross-Section of Return on Nifty 100 Companies: CAPM vs Fama-French Three-Factor Model. Universal Journal of Accounting and Finance, 10(2), 444 - 449. DOI: 10.13189/ujaf.2022.100208.

Copyright $\odot 2022$ by authors, all rights reserved. Authors agree that this article remains permanently open access under the terms of the Creative Commons Attribution License 4.0 International License

\begin{abstract}
In order to explain the relationship between risk and expected return, different researchers use different asset pricing models. In this research paper, we identify whether Sharpe's single factor model termed Capital Asset Pricing Model or Fama-French three-factor model better explains the expected excess return on portfolio. We used NIFTY INDEX as the proxy market portfolio. For the purpose of FF Model, we used Market Capitalization (MC) as a variable of firm size and Book to Price $(\mathrm{B} / \mathrm{P})$ as a variable of firm value. Data are taken from $1^{\text {st }}$ July 2012 to $30^{\text {th }}$ June 2021 for 85 companies forming part of NSE 100. We have used the same portfolio selection framework used by Fama-French (1993 and 1996). 91 days treasury bills (T-bills) have been used as risk-free proxy and taken from RBI website for the given period. We found that Fama-French three-factor model captured better results than the single factor CAPM in explaining the expected returns for all the double-sorted portfolios constructed based on MC (size factor) and B/P (value factor).
\end{abstract}

Keywords Risk, Expected Return, Capital Asset Pricing Model, Firm Size, Firm Value, FF Three-Factor Model

JEL classification: G12; G14

\section{Introduction}

The capital asset pricing model (CAPM) of Sharpe (1964), Lintner (1965) and Mossin (1966), based on pathbreaking work of Markowitz (1952) is the backbone of the current portfolio philosophy. According to CAPM, the expected excess return of the security is in proportion to the single explanatory factor i.e., expected excess market return, the proportion being beta as a relative measure of volatility of the security. However, Fama and French (1992) incorporated two additional variables or factors and concluded that stock returns are dependent not only on volatility but also on a combination of firm size and firm value. Size, characterized by market capitalization, is an absolute concept and value characterized by ratio of book value to market value, is a relative concept. The model prophesies that high $\mathrm{B} / \mathrm{M}$ value and small size stocks are given a premium, and are an active two determinants of the expected return of the security besides the third one excess market return in proportion to its beta. Thus, portfolios with a significant number of small size stocks and value stocks are likely to perform better than those with large firm stocks and growth stocks. The three-factor model (Fama and French, 1992, 1993, 1996) is expected to perform better than CAPM in pricing risky assets through its exposure to two additional factors. 
The rest of paper is divided in four sections. Section II traces the Literature Review relevant to the travel path between the advent of CAPM and FF three-factor model. Section III frames the research hypotheses for the current study. Section III also explains the data and methodology employed to address the hypotheses. Section IV analyses the results of the study. Section $\mathbf{V}$ Concludes the study and identifies areas for further research.

\section{Literature Review}

Stock / Portfolio price analysis in terms of its return (increase/decrease in price) and risk (Variability in return) was first addressed by Markowitz (1952) and ever since has been a favorite with researchers. What shall be the price of an asset commensurate with the underlying risk was addressed by positive Capital Asset Pricing Model (CAPM) of Sharpe (1964), Lintner (1965) and Mossin (1966) with a suitable generalized modification by Black et al (1972). Fama and MacBeth (1973) supported CAPM model. Arbitrage Pricing Theory (APT) was developed by Ross (1976), an alternative to CAPM for explaining the expected returns of portfolio. However, it opened the gates for multi-factors as explanations for contributors of risk to a security and hence potential candidates for risk premium while pricing those risky assets. Several authors identified other factors that influence average stock returns. Banz discovered size effect (1981). Basu (1983) discovered a positive relation between Earning to Price and average return. Bhandari (1988) discovered that average return is positively related to leverage. Value effect is documented by Chan (1991). Fama and French $(1993,1996)$ rejected the CAPM and developed their three-factor asset pricing model with two other factors, size effect (market capitalization as a size variable) and value effect (Book Equity to Market Equity as a value variable) which explain significant return patterns. Jegadeesh and Titman (1993) discovered momentum strategy. Loughran and Ritter (1995) found the net stock issues anomaly. Sloan (1996) documented the accrual anomaly. He explored that single factor (beta) cannot predict the future expected returns. Accrual and cash flow information should be reflected for future expected return. Fama and French (2008) tested few new anomalies like net stock issues, accruals, momentum, asset growth and profitability. They found a significant relation between average stock returns and net stock issues, accruals, momentum anomalies but less significant with other two anomalies.

Connor and Sehgal (2001) supported Fama-French model in India and found strong presence of size, value and market beta factors in stock returns. Study of Bhal (2006) concluded that the three-factor FF model explained the cross-section of returns in the portfolio better than its variants and CAPM. Taneja (2010) tested Fama French three-factor model on the Indian stock market to verify the CAPM and three-factor model of FF's ability to interpret the cross-section of the Indian stock market Returns. He found FF3F model better than CAPM. Sehgal and Balakrishnan (2013) mentioned that the three-factor FF model cannot fully explain the abnormal returns lost by CAPM. Sobti (2016) included the impact of the 2008 global financial crisis in its research. He found that the three-factor FF model is better than CAPM. He also discovered the non-linear relationship between CAPM's excesses return and beta. Sreenu (2018) found that the three-factor FF model can better explain the rate of return on equities and the expected rate of return from the capital market. The study concluded that both SMB and HML factors provide good explanatory control over changes in equity returns, but the relationship between HML factors and portfolio returns is more continuous.

The current paper continues that streak in further establishing the robustness of the FF 3 factor model and its perceived superiority over traditional CAPM by looking at the data for the latest period from 2012 to 2021 .

\section{Research Hypotheses}

We have tested following hypotheses in our research:

1) CAPM holds itself in Indian equity market.

2) Fama-French Three Factor model holds itself in Indian equity market.

3) Three-Factor model of Fama-French is a better model than single factor model of Sharpe (CAPM) in explaining the expected return.

\section{Data \& Methodology}

The present study is based on the month end prices of companies included in Nifty 100 index. The sample companies are forming part of NIFTY 100, a wide market index covering 17 industries. The NIFTY 100 follows the performance of a combined portfolio of two indices, NIFTY 50 and NIFTY Next 50. These sample companies represent more than $70 \%$ of market capitalization and daily trading volume in India. The sample period is June 2012 to July 2021. However, due to inadequate data in some securities, 15 companies were dropped and our final data set consists of month end adjusted closing share prices for 85 companies from the year June 2012 to July 2021. In India, Financial year starts from $1^{\text {st }}$ April, but we have not formed our portfolios in that month. Rather a lag of 3 month was taken as the company data takes time to come to market and is available for analysis.

The month end adjusted closing share price data has been converted into return data from July 2012 to June 2021. In all, we have 108 observed returns for these 85 shares as a monthly return series.

Nifty 50, a bellwether index of Indian economy and a widely tracked number is being used as market surrogate, and its monthly closing value is accordingly converted into monthly return series. 91 days treasury bills (T-bills) have 
been used as risk-free proxy and it's taken from the website of RBI. Since 91 days treasury bills (T-bills) were available on weekly basis, hence in order to make it comparable, we converted weekly data into monthly data by taking average.

For CAPM, Beta (b) is calculated by running a simple regression, so monthly excess returns on equally weighted cross section portfolio for 108 months under consideration are regressed on excess return on Nifty 50 over and above the monthly 91-days T Bill, wherein excess market returns are the independent variable and excess cross-section portfolio returns are the dependent variable. The equation is

$$
\left(R_{i}-R_{f}\right)=a+b\left(R_{m}-R_{f}\right)+e
$$

Where;

$\mathrm{R}_{\mathrm{i}}-\mathrm{R}_{\mathrm{f}}=$ Excess returns on portfolio $\mathrm{i}$

$\mathrm{a}=$ Intercept

$b=$ Beta which measures the sensitivity of the Excess portfolio return to variation in the Excess market return.

$\mathrm{R}_{\mathrm{m}}-\mathrm{R}_{\mathrm{f}}=$ Excess returns on market $\mathrm{m}$

$\mathrm{e}=$ error terms

For the purpose of FF Model, we have taken Market Capitalization as on $30^{\text {th }}$ June of every year from 2012 to 2021 and used as a variable of firm size. Also, we have taken P/B as on $31^{\text {st }}$ march of every year as per our data set. We have further converted $\mathrm{P} / \mathrm{B}$ data into $\mathrm{B} / \mathrm{P}$ data by just doing the reverse of it and used as a variable of firm value. The complete data has been taken from CMIE PROWESS, provider of financial information for Indian companies.

To capture the size and value effect, we constructed portfolio on the basis of company size and company value, where size is defined as Market capitalization and value as Book to Price ratio. Every year starting from June 2012 (t), We first sorted our data on the basis of size (MC) and all the sample companies were classified into two groups, small (S) and big (B). The bottom 50 percent companies (43 Companies) are classified under small (S) firm category and the top 50 percent companies (42 Companies) are under big (B) firm category. We further sorted our data on the basis of company value $(\mathrm{B} / \mathrm{P})$ obtained on $31^{\mathrm{st}}$ March of period $\mathrm{t}$ and divided the sample companies into three groups, low (L), medium $(\mathrm{M})$ and high $(\mathrm{H})$. The bottom 30 percent companies (26 Companies) are classified under low (L) firm category, 40 percent companies (34 Companies) are classified under medium (M) firm category and the top 30 percent companies (25 Companies) are classified under high $(\mathrm{H})$ firm category.

We then formed Six portfolios from the combination of two size $(\mathrm{MC})$ and three value $(\mathrm{B} / \mathrm{P})$ category $(\mathrm{B} / \mathrm{H}, \mathrm{B} / \mathrm{M}$, $\mathrm{B} / \mathrm{L}, \mathrm{S} / \mathrm{H}, \mathrm{S} / \mathrm{M}, \mathrm{S} / \mathrm{L}$ ) where, $\mathrm{B} / \mathrm{H}$ portfolio indicates stocks in the big size category and in the high value category while S/L portfolio indicates stocks in the small size category and also in the low value category. We figured out there are 13 companies under the $\mathrm{B} / \mathrm{H}, 19$ companies under the $\mathrm{B} / \mathrm{M}, 10$ companies under the $\mathrm{B} / \mathrm{L}, 12$ companies under the $\mathrm{S} / \mathrm{H}, 15$ companies under the $\mathrm{S} / \mathrm{M}$, and 16 companies under the S/L category in 2012 .

The monthly equally weighted excess returns on these six portfolios were computed from July 2012(t) to June $2013(t+1)$, and then the portfolios were re-formed in June of year $t+1$ and the entire process of portfolio formation and return generation was repeated up to June 2021. We found different counts in all the categories every year.

\section{Factor Mimicking Portfolios}

The Fama and French (1993) use three explanatory variables for explaining the cross-section of the stock returns.

- The excess market return factor i.e. the market index returns minus the risk-free return $\left(R_{m}-R_{f}\right)$. This is calculated from the NSE nifty index.

- The risk factor in return related to Size (Small minus Big) (SMB). The risk factor is mimicked by taking a simple average of the monthly returns of the three big size portfolios $(\mathrm{B} / \mathrm{L}, \mathrm{B} / \mathrm{M}, \mathrm{B} / \mathrm{H})$ and subtracting it from the average of the three small size portfolios (S/L, S/M, S/H). It mimics the monthly returns of the SMB factor.

SMB (Small minus Big) = average returns of small size firms minus average returns of big size firms $=1 / 3$ of $(\mathrm{S} / \mathrm{H}$ $+S / M+S / L)-1 / 3$ of $(B / H+B / M+B / L)$.

The risk factor in return related to Value i.e. High minus Low (HML). Each month, the difference between the simple averages of the returns on the two high $\mathrm{B} / \mathrm{P}$ and two low $\mathrm{B} / \mathrm{P}$ is calculated. It mimics the monthly returns of the HML factor.

HML (High minus Low) = average returns of high $B / P$ ratio minus average returns of low $B / P$ ratio $=1 / 2$ of $(S / H+B / H)-1 / 2$ of $(S / L+B / L)$.

Then, for Fama and French three-factor model, the excess returns on equally weighted cross section portfolio are regressed with $\left(\mathrm{R}_{\mathrm{m}}-\mathrm{R}_{\mathrm{f}}\right)$, (SMB), and (HML) as independent variables and $\mathrm{R}_{\mathrm{i}}-\mathrm{R}_{\mathrm{f}}$ as the dependent variable for obtaining corresponding coefficients for the independent variables.

$$
\begin{aligned}
\mathrm{R}_{\mathrm{i}}-\mathrm{R}_{\mathrm{f}}=\mathrm{a}+\mathrm{b}_{1}\left(\mathrm{R}_{\mathrm{m}}-\mathrm{R}_{\mathrm{f}}\right)+\mathrm{b}_{2}(\mathrm{SMB})+ & \\
& +\mathrm{b}_{3}(\mathrm{HML})+\mathrm{e}
\end{aligned}
$$

where, SMB and HML are size and value factors.

\section{Result Analysis}

Now we turn to the analysis of the results of our sorting of securities into double sorted portfolios and their consequent regressions under equation 1 (CAPM) and equation 2 (FF Model).

Table 1 shows the descriptive statistics of average 
excess returns of portfolios classified by market capitalization $(\mathrm{MC})$ and book to price $(\mathrm{B} / \mathrm{P})$. It clearly shows that the $\mathrm{S} / \mathrm{H}$ portfolio (1.96\%) outperforms the $\mathrm{B} / \mathrm{L}$ portfolio $(.68 \%)$, indicating strong size and value effects. The annualized difference is quite significant around $16 \%$.

We find that the expected return of the portfolios classified by $\mathrm{MC}$ and $\mathrm{B} / \mathrm{P}$ can be explained by comparing the two asset pricing models, the CAPM and the FF3F. We attempt it one after the another.

Table 2 shows risk-adjusted abnormal returns from sample portfolios using CAPM as a standard for asset pricing. To estimate the CAPM in its best way, we look at the excess return version of market factor model and expect the alpha values should be close to zero. The results are mixed. For the complete cross section of return, the alpha is significant at 5\%. However, the alpha values of all small portfolios (S/H, S/M and S/L) are statistically significant at $5 \%$ level, and signify that CAPM has not been able to capture their expected return based on beta alone. We are not very sure if the CAPM holds in the Indian market as results support the insignificant alpha values of big portfolios.

The overall model has explanatory power of $91.2 \%$ as supported by $\mathrm{R}^{2}$, but when individual double sorted portfolios are considered, it reduces substantially.

Table 3 presents regression results using the FF3F model. The results are far more encouraging. The t-statistics for all alpha values are insignificant and point to the fact it is statistically very close to zero for all double sorted portfolios as well as the complete cross section portfolio. Also, the adjusted $\mathrm{R}^{2}$ values of all portfolios are higher than the CAPM. However, the $t$ values for coefficient of SMB are significant for big portfolios. So, we cannot completely agree on the applicability of FF 3-factor model in Indian stock market. However, its results are certainly better than those of CAPM as characterized by higher $\mathrm{R}^{2}$ value.

Furthermore, the FF3F model appears to outperform the CAPM as it has a higher adjusted $\mathrm{R}^{2}$.

Table 1. Average Excess Returns based on Portfolios classified by MC and B/P

\begin{tabular}{|c|c|c|c|c|c|c|}
\hline MC-BP & & & & & & \\
\hline Portfolio & Excess S/H & Excess S/M & Excess S/L & Excess B/H & Excess B/M & Excess B/L \\
\hline $\begin{array}{c}\text { Average Excess } \\
\text { return }\end{array}$ & 0.019622 & 0.016799 & 0.017207 & 0.003026 & 0.006845 & 0.006864 \\
\hline
\end{tabular}

Table 2. CAPM Results based on Portfolios classified by MC and B/P

$$
R_{\mathrm{i}}-R_{\mathrm{f}}=\mathrm{a}+\mathrm{b}\left(\mathrm{R}_{\mathrm{m}}-\mathrm{R}_{\mathrm{f}}\right)+\mathrm{e}
$$

\begin{tabular}{|c|c|c|c|c|c|}
\hline MC-BP & & & & & \\
\hline Portfolio & $\mathrm{a}$ & $\mathrm{b}$ & $\mathrm{t}(\mathrm{a})$ & $\mathrm{t}(\mathrm{b})$ & $\mathrm{R}^{2}$ \\
\hline $\begin{array}{c}\text { Excess Complete } \\
\text { Cross-section }\end{array}$ & 0.00626555 & 0.9721141 & 4.38105447 & 33.145093 & 0.91200378 \\
\hline Excess S/H & 0.012429735 & 1.201177961 & 3.0121645 & 14.19407042 & 0.655252752 \\
\hline Excess S/M & 0.011138615 & 0.94533241 & 3.92889424 & 16.25947304 & 0.713800072 \\
\hline Excess S/L & 0.012919336 & 0.716205367 & 4.73687745 & 12.80478575 & 0.607352929 \\
\hline Excess B/H & -0.00416377 & 1.200749302 & -1.3831853 & 19.45040164 & 0.781135591 \\
\hline Excess B/M & 0.000634207 & 1.037269686 & 0.38339822 & 30.57692279 & 0.898169766 \\
\hline Excess B/L & 0.002608705 & 0.71073925 & 1.16947973 & 15.5367714 & 0.694868552 \\
\hline
\end{tabular}

Table 3. Fama-French Model Results based on Portfolios classified by $\mathrm{MC}$ and $\mathrm{B} / \mathrm{P}$ $R_{i}-R_{f}=a+b 1\left(R_{m}-R_{f}\right)+b 2(S M B)+b 3(H M L)+e$

\begin{tabular}{|c|c|c|c|c|c|c|c|c|c|}
\hline MC-BP & & & & & & & & & \\
\hline Portfolio & $\mathrm{a}$ & $\mathrm{b} 1$ & $\mathrm{~b} 2$ & $\mathrm{~b} 3$ & $\mathrm{t}(\mathrm{a})$ & $\mathrm{t}(\mathrm{b} 1)$ & $\mathrm{t}(\mathrm{b} 2)$ & $\mathrm{t}(\mathrm{b} 3)$ & $\mathrm{R}{ }^{2}$ \\
\hline $\begin{array}{c}\text { Excess } \\
\text { Complete } \\
\text { Cross-section }\end{array}$ & -0.00016 & 0.97115 & 0.52490 & 0.03284 & -0.13511 & 41.59457 & 10.27529 & 1.42828 & 0.95876 \\
\hline Excess S/H & 0.00105 & 0.92543 & 1.09578 & 0.63011 & 0.48499 & 21.66297 & 11.72358 & 14.97345 & 0.93504 \\
\hline Excess S/M & -0.00196 & 0.99988 & 1.03560 & -0.05096 & -0.78641 & 20.40795 & 9.66079 & -1.05587 & 0.84972 \\
\hline Excess S/L & 0.00063 & 0.94468 & 0.86368 & -0.41786 & 0.31774 & 24.14211 & 10.08806 & -10.84076 & 0.85790 \\
\hline Excess B/H & -0.00029 & 0.91136 & -0.14020 & 0.58539 & -0.13704 & 21.90598 & -1.54022 & 14.28419 & 0.92650 \\
\hline Excess B/M & -0.00012 & 1.06653 & 0.04335 & -0.05747 & -0.05794 & 27.32914 & 0.50772 & -1.49484 & 0.90035 \\
\hline Excess B/L & 0.00013 & 0.89211 & 0.09190 & -0.36664 & 0.06699 & 23.12313 & 1.08872 & -9.64728 & 0.83952 \\
\hline
\end{tabular}


It is quite evident that alpha of CAPM regression for complete portfolio is significant and supports the view that beta as an explanatory variable of expected return is insignificant. A multi-factor Fama-French model applied on the same data, returned an insignificant alpha. It was supportive of the fact that three factors collectively explained the expected return of the complete portfolio better and more holistically. The power of the regression as explained by coefficient of determination, $\mathrm{R}^{2}$ increased from $91.2 \%$ to $95.87 \%$.

In terms of our hypothesis, H1 about applicability of CAPM in Indian stock markets, we expected the alphas to be equal to zero. However the results are mixed and support only the big stocks, which turn out insignificant alphas and better $\mathrm{R}^{2}$. The results indicated that small portfolios defined by market capitalisation and High value portfolios defined by $\mathrm{B} / \mathrm{P}$ ratio performed better than big portfolios and low value portfolios. They were indicative of the existence of small firm and high value effects propagated by Fama-french in their seminal article.

In terms of $\mathrm{H} 2$ about applicability of Fama-french 3 -factor model, the results are superior as they return all insignificant alphas on composite level as well as granular level of factor mimicking portfolios. The results better explain the expected return on stocks and consequent portfolios.

In terms of H3, Fama-French 3-factor model is superior to CAPM as its $\mathrm{R}^{2}$ based on complete cross section increased from $91.2 \%$ to $95.87 \%$. All factor mimicking portfolios performed better when their expected returns were explained through Fama-french rather than CAPM model. The respective $\mathrm{R}^{2}$ of $\mathrm{S} / \mathrm{H}$. S/M, S/L, B/H, B/M and $\mathrm{B} / \mathrm{L}$ increased from $65.5 \%, 71.3 \%, 60.7 \%, 78.1 \%, 89.8 \%$ and $69.4 \%$ in CAPM regression to $93.5 \%, 84.9 \%, 85.7 \%$, $92.6 \%, 90 \%$ and $83.9 \%$ when regressed to three factors of Fama-french, respectively.

\section{Conclusions \& Further Research}

The expected returns and their volatility as captured by standard deviation have been a staple for security analysts and portfolio managers ever since Markowitz (1952) unravelled it, and the quest for explanatory variables for expected returns has moved from single factor (beta of the portfolio) explanation of Sharpe (1964) to three-factor explanation (Beta, size and value of portfolio) pioneered by Fama-french (1993), as a result of unravelling of many anomalies in stock pricing ever since Sharpe coined the Capital asset Pricing Model (CAPM). Although of late, many more attempts including Carhart's Four factor models (1997) and Fama-French Five factor model (2014) have increased the intensity of debate and the search for those elusive factors explaining the expected returns of financial assets and the classic comparison between CAPM and Fama-french Three-factor models have been continued to be examined in different geographical and temporal settings. The current paper has tried to address the same problem in the most recent decades in one of the most progressive nations in the world, India.

In this paper, we estimated regression equations and tried to test which factor models (CAPM or FF 3 Factor model) can better explain the expected return of stocks in Indian markets. Through regression approach, we conducted different hypotheses tests to check the statistical significance of key parameters (Intercept, market beta, size (SMB), value (HML). The research concluded that the CAPM model does not fully explain the abnormal returns of the portfolios, and further the Fama and French three-factor model performed better than CAPM as its $\mathrm{R}^{2}$ for overall cross section regression as well as on all factor mimicking portfolios was superior. The paper established that small size and value stocks outperformed big size and growth stocks in Indian stock markets during the recent period of 2012-2021.

Every research has its own limitations, like here we have considered only one variable for size (MC) and value factor $(\mathrm{B} / \mathrm{P})$. We restricted our research to the level that we mentioned because of limited scope of the study and time constraint. Further, we have extracted our data from Nifty 100 and our study period is limited to 9 years from 2012 to 2021. Our research is limited to a relative comparison of CAPM and FF3F model. There have been alternative explanations as provided by four-factor model developed by Carhart (1997) and Five-factor model developed by Fama and French (2014) and should be given due attention. It would be interesting to explore whether these models can increase the effectiveness in unravelling the most appropriate factors explaining the expected returns of the financial securities.

\section{REFERENCES}

[1] Bahl, Bhavna, 2006 "Testing the Fama and French Three-Factor Model and its Variants for the Indian Stock Returns", SSRN Electronic Journal, 10.2139/ssrn.950899.

[2] Banz, Rolf W., 1981, "The Relationship between Return and Market Value of Common Stocks", Journal of Financial Economics 9, 3-18.

[3] Basu, Sanjoy, 1983, "The Relationship between Earnings Yield, Market Value, and Return for NYSE common stocks: Further Evidence", Journal of Financial Economics 12, 129-156.

[4] Bhandari, Laxmi Chand, 1988, "Debt/Equity Ratio and Expected Common Stock Returns: Empirical Evidence", Journal of Finance 43, 507-528.

[5] Black, Fischer, 1972, "Capital Market Equilibrium with Restricted Borrowing”, Journal of Business, 45(3), 444-455.

[6] Carhart, Mark M., 1997, "On Persistence in Mutual Fund Performance", Journal of Finance 52(1), 57-82. 
[7] Chan, L.K.C., Hamao, Y., \& Lakonishok, J., 1991, "Fundamentals and stock returns in Japan". Journal of Finance, 46, 1739-1764.

[8] Connor, Gregory and Sehgal, Sanjay, 2001. "Tests of the Fama and French Model in India”, Working Paper, 1-23.

[9] Fama, Eugene F., and Kenneth R. French, 1992, "The Cross-Section of Expected Stock Returns", Journal of Finance 47, 427-465.

[10] Fama, Eugene F., and French, Kenneth R., 1993, 'Common Risk Factors in the Returns on Stocks and Bonds", Journal of Financial Economics 33, 3-56.

[11] Fama, Eugene F., and French, Kenneth R., 1996, "Multifactor Explanations of Asset Pricing Anomalies", Journal of Finance 51, 55-84.

[12] Fama, Eugene F., \& French, Kenneth R., 2008, "Dissecting Anomalies, Journal of Finance, Vol.63, No.4, pp.1653-1678.

[13] Fama, Eugene F., and French, Kenneth R., 2014, "A Five Factor Asset Pricing Model", Journal of Financial Economics 116(1), 1-22.

[14] Fama, Eugene F., and MacBeth, James D., 1973, "Risk, Return, and Equilibrium: Empirical Tests", Journal of Political Economy 81(3), 607-636

[15] Jegadeesh, Narasimhan and Sheridan Titman, 1993, "Returns to Buying Winners and Selling Losers: Implications for Stock Market Efficiency", Journal of Finance 48, 65-91.

[16] Lintner, John, 1965, "The Valuation of Risk Assets and The Selection of Risky Investments in Stock Portfolios and Capital Budgets", Review of Economics and Statistics 47, 13-37.
[17] Loughran, T., \& Ritter, J. R., 1995, "The new issues puzzle", Journal of Finance, 50, 23-51.

[18] Markowitz, Harry, 1952. "Portfolio Selection", Journal of Finance 7(1), 77-91.

[19] Mossin, Jan, 1966, "Equilibrium in a Capital Asset Market", Econometrica , Oct., 1966, Vol. 34, No. 4 (Oct., 1966), pp. 768-783

[20] Ross, Stephen A., 1976, "The Arbitrage Theory of Capital Asset Pricing", Journal of Economic Theory 13(3), 341-360.

[21] Sehgal, Sanjay, and Balakrishnan, A., 2013. "Robustness of Fama-French Three Factor Model: Further Evidence for Indian Stock Market", Journal of Business Perspective 17(2), 119-127.

[22] Sharpe, William F., 1964, "Capital Asset Prices: A Theory of Market Equilibrium under Conditions of Risk", Journal of Finance 19, 425-442.

[23] Sloan, R., 1996, "Do stock prices fully reflect information in accruals and cash flows about future earnings? The Accounting Review, 71, 289-315.

[24] Sobti, Neharika, 2016, "Revisiting CAPM and FF Three Factor Model in Indian Equity Market”, Business Analyst 37(1), 31-46.

[25] Sreenu, Nenavath, 2018, “An Empirical Test of Capital Asset-Pricing Model and Three-Factor Model of Fama in Indian Stock Exchange', SAGE Publications 43(4), 294307.

[26] Taneja, Yas Pal, 2010. "Revisiting Fama French Three-Factor Model in Indian Stock Market", Journal of Business Perspective 14(4), 267-274. 